\title{
Effect of Blending of Fats and Oils on Physico-chemical Properties of Ghee
}

\author{
Niranjan, G. Poojitha*, C. Kempanna and B. G. Shilpashri \\ Dairy Chemistry Division, Dairy Science College, KVAFSU, \\ Hebbal, Bangalore 560024, India \\ *Corresponding author
}

\section{A B S T R A C T}

\section{Keywords \\ Physico-chemical properties, Ghee, Fats and oils, Level of blending \\ Article Info \\ Accepted: \\ 10 July 2020 \\ Available Online: \\ 10 August 2020}

The changes in the ghee physico-chemical properties due to blending with different fats and oils at different levels were studied. Ghee was blended with Groundnut oil, Coconut oil, Hydrogenated fat and animal body fat at $10 \%$ and $15 \%$ respectively. The blended ghee samples were analysed for Reichert-Meissl, Polenske, saponification, iodine values and butyro refractometer reading at $40^{\circ} \mathrm{C}$. The study revealed that an increase in B.R. reading and Iodine value are due to blending with groundnut oil and hydrogenated fat, also an increase in the polenske and saponification values are due to blending with coconut oil where as decrease in the B.R. reading and Iodine value are due to blending with coconut oil and decrease in the Reichert-Meissl, Polenske, saponification values are due to blending with hydrogenated fat and animal body fat at $10 \& 15$ per cent respectively.

\section{Introduction}

Ghee is well known for characteristic flavor aroma and taste. It is widely used in the preparations of culinary purpose and also in the preparation of sweets occupying important place in Indian diets. India produces approximately 5.34 million tonnes of ghee annually (BAHFS, 2015). It has got unique fatty acid profile ranging from short chain, long chain, saturated and unsaturated fatty acids besides having fat soluble vitamins A, $\mathrm{D}, \mathrm{E}$ and $\mathrm{K}$. It is a premium fat rich dairy product, attaining commercial significance to dairy industry.
Because of the seasonal variation the supply of milk and ghee falls short of demand resulting in the producers or the middle-men involved in the ghee trade, tend to adulterate ghee with cheaper oils and fats like vegetable oils, animal body fats, hydrogenated fats and sometimes even the non-edible mineral oils, especially during lean season to earn more money. Thus the problem of adulteration has assumed a very serious dimension.

Milk fat, like other fats and oils, is characterized by certain physicochemical properties i.e., Reichert-Meissl (RM) value, Poleske value, saponification value, iodine value, butyro-refractometer (BR) reading and 
free fatty acids(FFA)which have been found to be the basis for the fixation of certain physicochemical constants for defining the chemical quality of the product. These constants serve as an indication of the types of component fatty acids present in fats. They also enable the detection of fat adulteration qualitatively and, in some instances, quantitatively.

These physicochemical properties, however, exhibit some natural variation depending upon factors such as method of manufacture, age and condition of the sample, species, breed, individuality of animal, stage of lactation, number of lactation (age of animal), season of the year, region of the country, feed of the animal (Doctor et al., 1940; Aneja et al., 2002; De 2005).

In order to ensure a genuine pure safer quality product to the consumer, the government of India has prescribed the compositional standards for ghee, under FSSAI and AGMARK rules. FSSAI (2011) has prescribed the requirements for two physicochemical constants, namely B.R. reading at $40{ }^{\circ} \mathrm{C}$ and $\mathrm{RM}$ value, plus FFA (as oleic acid) and moisture for defining the quality of milk fat in terms of ghee/anhydrous milk fat/anhydrous butter fat. While, AGMARK standards (AGMARK, 1981) specify the physicochemical constant, that is B.R. reading, RM value and Polenske value, besides FFA and moisture for the same purpose. The other three physicochemical constants such as iodine value, saponification value and Polenske value for milk fat range between 26 and 35, 210 and 233 and 1.2 and 2.4, respectively (Jenness and Patton 1969).

In the present article different market, desi and control ghee samples were blended with different fats and oils at two different percent $(10,15)$ and have checked for their effect on physico-chemical properties of ghee samples.

\section{Materials and Methods}

\section{Chemicals and reagents}

All the chemicals used during the investigation were AR grade and procured from standard suppliers (HI MEDIA®).

\section{Preparation of ghee sample}

Fresh cream was procured from student experimental dairy plant (SEDP) of Dairy Science College, Karnataka Veterinary Animal and Fisheries Sciences University (KVAFSU), Bangalore and used for the ghee preparation by the method given by De (2005). Some of the commercial branded as well as desi ghee samples which were procured from local market of Bangalore used to assess the physico-chemical quality and the purity.

\section{Ghee samples}

Samples of ghee from organized sector (samples A, B, C, D and E) and unorganized sector (samples F, G, H and I) were collected from local market of Bangalore.

\section{Blending of ghee samples with fats and oils}

For the blending of ghee samples, with blending agents like groundnut oil, coconut oil, hydrogenated fat and animal body fat, the blending agents were heated and maintained at $65-70^{\circ} \mathrm{C}$ for $10 \mathrm{~min}$ before blending, then they were blended to ghee samples individually at 10 and 15 per cent to study their impact on physico-chemical constants of ghee.

\section{Physico-chemical properties of ghee samples}

The ghee samples which were procured from the market, blended ghee samples with fats 
and oils and also the ghee which was prepared in the SEDP were analyzed for different physico-chemical constants like RM value, Polenske value, saponification value, iodine value and B.R. reading at $40^{\circ} \mathrm{C}$ to know their effect on physico-chemical properties of ghee by [SP: 18 (Part XI) - 1981].

\section{Statistical analysis}

The data was analyzed using $\mathrm{R}$ software $\{\mathrm{R}$ Programme, R-Version 3.1.3(2015-3-09), Copyright (C) 2015\} both one way and two way Completely Randomed Design (CRD) which is the most appropriate for the study.

\section{Results and Discussion}

\section{Effect of blending agents on physico- chemical constants of ghee}

In the present study different fats and oils were blended at varied levels to check the variation in the physico-chemical constants of ghee.

\section{B. R. reading}

Butyro-Refractometer reading increases with the increase in blending of groundnut oil. The control, market, and desi ghee samples scored a B.R. reading of $43,44.5$ and 44.5 at $0 \%$ adulteration. When these ghee samples were blended with groundnut oil at $15 \%$ the value was increased to 44, 44.5, and 45 respectively. Upadhyaya (2014) also reported that, there is an increase in the B.R. reading when the ghee samples were adulterated with groundnut oil.

From the (table 1) it is seen that the B.R. reading decreases with an increase in blending with coconut oil. When ghee was adulterated with coconut oil at $10 \%$ level, the B.R. reading was 42.5 . When the level of adulteration was increased to $15 \%$ the value of B.R. reading was decreased to 42.0. The control ghee showed an average B.R. reading of 43.0. Similar results were seen in case of desi and market ghee samples. The decrease in the B.R. reading of ghee when it is adulterated with coconut oil is mainly due to the presence of short chain fatty acids like lauric, palmitic acids in higher amount. Zachariah (2010) also reported that, there is a decrease in BR of milk fat when the ghee was blended with coconut oil at 10, 20 per cent. When the ghee samples were blended with hydrogenated fat and animal body fat at 10 , $15 \%$ level showed an increase in the B.R. reading value (table 1 ).

\section{Iodine value}

Iodine value is a measure of the extent of unsaturation of fat. The value varies with the type and proportion of unsaturated fatty acids present in a fat. Ghee contains about $35 \%$ of total unsaturated acids, most of which consists of oleic acid; the IV of ghee lies around 30.

In the present investigation the iodine value of control, market and desi ghee samples recorded the values of $34.5,33.79$, and 34.76 , respectively. The blending of $\mathrm{GO}, \mathrm{CO}, \mathrm{HF}$ significantly altered the iodine value, while the recorded adulteration with respect to $\mathrm{ABF}$ blending found to be non-significant.

The blending of GO and $\mathrm{HF}$ at 15 per cent level had significantly increased the iodine value from 34.50 to 46.21 and 43.18 respectively in control ghee. When the same control ghee is blended with $\mathrm{CO}$ at 15 per cent level the value decreased to 28.22. By blending of $\mathrm{CO}$ there is a decrease in the iodine value is observed it is mainly due to coconut oil is having an Iodine Value of around 8-9, lower than ghee. So, lower Iodine Value can be observed in ghee by adulteration with Coconut oil (Bolton, 1999). 


\section{Reichert-Meissl value}

RM value is the measure of steam volatile water soluble fatty acids (butyric acid and caproic acid). In the present study the RM value of control, market and desi ghee samples recorded the value of 26.8, 23.36 and 23.83 respectively.
There is a decreasing effect on RM value, with an increase in blending of $\mathrm{GO}, \mathrm{CO}, \mathrm{HF}$ and $\mathrm{ABF}$ in control, market and desi ghee samples (Table.3). Control ghee showed a values of $23.38,23.95,23.33$ and 23.38 when blended with $\mathrm{GO}, \mathrm{CO}, \mathrm{HF}$ and $\mathrm{ABF}$ at 15 per cent respectively.

Table.1 Studies on the impact of adulterants on B.R. reading

\begin{tabular}{|c|c|c|c|c|c|c|c|c|c|c|}
\hline \multirow{2}{*}{$\begin{array}{c}\text { Ghee } \\
\text { samples }\end{array}$} & \multirow{2}{*}{$\begin{array}{l}\text { BR } \\
0 \%\end{array}$} & \multicolumn{2}{|c|}{ GO } & \multicolumn{2}{|c|}{$\mathrm{CO}$} & \multicolumn{2}{|c|}{ HF } & \multicolumn{2}{|c|}{ ABF } & \multirow{2}{*}{$\underset{(\mathbf{P}<\mathbf{0 . 0 5})}{\mathbf{C D}}$} \\
\hline & & $10 \%$ & $15 \%$ & $10 \%$ & $15 \%$ & $10 \%$ & $15 \%$ & $10 \%$ & $15 \%$ & \\
\hline Control & $43.0^{\mathrm{a}}$ & $43.50^{b}$ & $44.0^{b}$ & $42.50^{b}$ & $42.0^{\mathrm{b}}$ & $44.0^{\mathrm{b}}$ & $44.50^{\mathrm{b}}$ & $43.0^{\mathrm{a}}$ & $43.50^{\mathrm{a}}$ & 0.40 \\
\hline Market & $44.50^{\mathrm{a}}$ & $45.0^{\mathrm{b}}$ & $45.50^{b}$ & $44.0^{\mathrm{b}}$ & $43.50^{b}$ & $44.50^{\mathrm{b}}$ & $45.0^{\mathrm{b}}$ & $45.0^{\mathrm{b}}$ & $45.50^{\mathrm{b}}$ & 0.38 \\
\hline Desi & $44.50^{\mathrm{a}}$ & $45.0^{\mathrm{b}}$ & $45.50^{b}$ & $44.0^{\mathrm{b}}$ & $43.50^{b}$ & $45.0^{\mathrm{b}}$ & $45.50^{\mathrm{b}}$ & $45.0^{\mathrm{b}}$ & $45.50^{\mathrm{b}}$ & 0.32 \\
\hline
\end{tabular}

Table.2 Studies on the impact of adulterants on Iodine value

\begin{tabular}{|c|c|c|c|c|c|c|c|c|c|c|}
\hline \multirow{2}{*}{$\begin{array}{c}\text { Ghee } \\
\text { samples }\end{array}$} & \multirow{2}{*}{$\begin{array}{l}\text { IV } \\
0 \%\end{array}$} & \multicolumn{2}{|c|}{ GO } & \multicolumn{2}{|c|}{ CO } & \multicolumn{2}{|c|}{ HF } & \multicolumn{2}{|c|}{$\mathbf{A B F}$} & \multirow{2}{*}{$\begin{array}{c}\text { CD } \\
(\mathbf{P}<0.05)\end{array}$} \\
\hline & & $10 \%$ & $15 \%$ & $10 \%$ & $15 \%$ & $10 \%$ & $15 \%$ & $10 \%$ & $15 \%$ & \\
\hline Control & $34.50^{\mathrm{a}}$ & $43.19^{b}$ & $46.21^{b}$ & $30.20^{\mathrm{b}}$ & 28 & $40.65^{\mathrm{b}}$ & & $35.32^{\mathrm{a}}$ & & 2.8 \\
\hline Mark & & $.62^{\mathrm{b}}$ & $45.71^{b}$ & $29.82^{\mathrm{b}}$ & & $37.92^{b}$ & $39.92^{b}$ & $34.90^{\mathrm{a}}$ & $35.20^{\mathrm{a}}$ & 2.66 \\
\hline Desi & $34.76^{\mathrm{a}}$ & $43.61^{b}$ & $46.66^{\mathrm{b}}$ & $30.78^{b}$ & $28.79^{\mathrm{b}}$ & $40.89^{b}$ & $43.99^{b}$ & $35.92^{\mathrm{a}}$ & $36.72^{b}$ & 2.7 \\
\hline
\end{tabular}

Note:

- All the results are average of three trials.

- Similar superscripts indicate non - significance at the corresponding critical difference

- Statistical analysis was made only with the control ghee sample.

$\mathrm{GO}=$ groundnut oil, $\mathrm{CO}=$ coconut oil, $\mathrm{HF}=$ hydrogenated fat, $\mathrm{ABF}=$ animal body fat

Table.3 Studies on the impact of adulterants on $\mathrm{R} M$ value

\begin{tabular}{|c|c|c|c|c|c|c|c|c|c|c|}
\hline \multirow{2}{*}{$\begin{array}{c}\text { Ghee } \\
\text { samples }\end{array}$} & \multirow{2}{*}{$\begin{array}{c}\text { RM value } \\
0 \%\end{array}$} & \multicolumn{2}{|c|}{ GO } & \multicolumn{2}{|c|}{ CO } & \multicolumn{2}{|c|}{ HF } & \multicolumn{2}{|c|}{$\mathbf{A B F}$} & \multirow{2}{*}{$\begin{array}{c}\text { CD } \\
(\mathbf{P}<0.05)\end{array}$} \\
\hline & & $10 \%$ & $15 \%$ & $10 \%$ & $15 \%$ & $10 \%$ & $15 \%$ & $10 \%$ & $15 \%$ & \\
\hline Control & $26.80^{\mathrm{a}}$ & $24.40^{\mathrm{b}}$ & $23.38^{b}$ & $24.81^{b}$ & $23.95^{\mathrm{b}}$ & $24.38^{b}$ & $23.33^{b}$ & $24.38^{\mathrm{b}}$ & $23.38^{b}$ & 0.09 \\
\hline Market & $23.36^{\mathrm{a}}$ & $21.28^{b}$ & $20.37^{b}$ & $21.69^{b}$ & $20.96^{\mathrm{b}}$ & $21.25^{\mathrm{b}}$ & $22.33^{b}$ & $21.26^{b}$ & $20.34^{\mathrm{b}}$ & 0.18 \\
\hline Desi & $23.83^{\mathrm{a}}$ & $21.70^{\mathrm{b}}$ & $20.78^{b}$ & $22.11^{\mathrm{b}}$ & $21.37^{b}$ & $21.68^{b}$ & $20.74^{b}$ & $21.69^{b}$ & $20.74^{b}$ & 0.2 \\
\hline
\end{tabular}

Table.4 Studies on the impact of adulterants on Polenske value

\begin{tabular}{|c|c|c|c|c|c|c|c|c|c|c|}
\hline $\begin{array}{c}\text { Ghee } \\
\text { Samples }\end{array}$ & $\begin{array}{c}\text { Polenske } \\
\text { Value }\end{array}$ & \multicolumn{2}{|c|}{ GO } & \multicolumn{2}{|c|}{ CO } & \multicolumn{2}{c|}{ HO } & \multicolumn{2}{|c|}{ ABF } & $\begin{array}{c}\text { CD } \\
(\mathbf{P}<\mathbf{0 . 0 5})\end{array}$ \\
\cline { 2 - 10 } & $0 \%$ & $10 \%$ & $15 \%$ & $10 \%$ & $15 \%$ & $10 \%$ & $15 \%$ & $10 \%$ & $15 \%$ & \\
\hline Control & $1.21^{\mathrm{a}}$ & $1.11^{\mathrm{a}}$ & $1.06^{\mathrm{a}}$ & $2.10^{\mathrm{b}}$ & $2.48^{\mathrm{b}}$ & $1.14^{\mathrm{a}}$ & $1.08^{\mathrm{a}}$ & $1.14^{\mathrm{a}}$ & $1.07^{\mathrm{a}}$ & $\mathbf{0 . 2 8}$ \\
\hline Market & $1.46^{\mathrm{a}}$ & $1.34^{\mathrm{a}}$ & $1.29^{\mathrm{a}}$ & $2.32^{\mathrm{b}}$ & $2.70^{\mathrm{b}}$ & $1.36^{\mathrm{a}}$ & $1.31^{\mathrm{a}}$ & $1.38^{\mathrm{a}}$ & $1.33^{\mathrm{a}}$ & $\mathbf{0 . 4 0}$ \\
\hline Desi & $1.23^{\mathrm{a}}$ & $1.13^{\mathrm{a}}$ & $1.18^{\mathrm{a}}$ & $2.12^{\mathrm{b}}$ & $2.50^{\mathrm{b}}$ & $1.16^{\mathrm{a}}$ & $1.10^{\mathrm{a}}$ & $1.16^{\mathrm{a}}$ & $1.11^{\mathrm{a}}$ & $\mathbf{0 . 3 5}$ \\
\hline
\end{tabular}


Table.5 Studies on the impact of the adulterants on Saponification value

\begin{tabular}{|c|c|c|c|c|c|c|c|c|c|c|}
\hline \multirow{2}{*}{$\begin{array}{c}\text { Samples fats/ } \\
\text { oils }\end{array}$} & \multirow{2}{*}{$\begin{array}{c}\text { Saponificat } \\
\text { ion Value } \\
0 \%\end{array}$} & \multicolumn{2}{|c|}{ GO } & \multicolumn{2}{|c|}{ CO } & \multicolumn{2}{|c|}{ HO } & \multicolumn{2}{|c|}{$\mathbf{A B F}$} & \multirow{2}{*}{$\begin{array}{c}\text { CD } \\
(\mathbf{P}<0 . \\
\text { 05) }\end{array}$} \\
\hline & & $10 \%$ & $15 \%$ & $10 \%$ & $15 \%$ & $10 \%$ & $15 \%$ & $10 \%$ & $15 \%$ & \\
\hline Control ghee & $230.66^{\mathrm{a}}$ & $226.17^{b}$ & $224.52^{b}$ & $231.72^{\mathrm{a}}$ & $231.92^{\mathrm{a}}$ & $226.19^{b}$ & $224.32^{\mathrm{b}}$ & $226.20^{\mathrm{b}}$ & $224.81^{b}$ & 1.85 \\
\hline Market ghee & $233.0^{\mathrm{a}}$ & $228.62^{\mathrm{b}}$ & $226.14^{\mathrm{b}}$ & $234.64^{\mathrm{a}}$ & $234.82^{\mathrm{a}}$ & $229.11^{\mathrm{b}}$ & $227.20^{\mathrm{b}}$ & $228.86^{\mathrm{b}}$ & $224.21^{\mathrm{b}}$ & 1.42 \\
\hline Desi ghee & $232.0^{\mathrm{a}}$ & $228.15^{\mathrm{b}}$ & $226.68^{\mathrm{b}}$ & $231.22^{\mathrm{a}}$ & $231.84^{\mathrm{a}}$ & $228.48^{\mathrm{b}}$ & $226.76^{b}$ & $226.50^{\mathrm{b}}$ & $224.33^{\mathrm{b}}$ & 2.23 \\
\hline
\end{tabular}

The decreasing effect of these adulterants is mainly due to the absence of the $\mathrm{C}_{4}$ fatty acid (butyric acid) in the adulterants. Other ghee samples like market and desi ghee samples also showed a decrease in the values when blended with the GO, $\mathrm{ABF}$ and $\mathrm{HF}$ adulterants.

\section{Polenske value}

Polenske value is the measure of steam volatile water insoluble fatty acids (caproic and caprylic). In the present investigation the control, market and desi branded ghee samples recorded a polenske value of 1.21 , 1.46 and 1.23 respectively.

In the present investigation it was observed that (table 4) there was a decrease in the polenske value of control, market and desi ghee samples when they had blended with $\mathrm{GO}, \mathrm{HO}$ and $\mathrm{ABF}$ at 10 and 15 per cent. But there was an increase in the polenske value when these ghee samples were blended with coconut oil at both the level of adulteration. The control ghee had increased its value from 1.21 to 2.1 , and 2.48 at 10 per cent and 15 per cent level of adulteration with coconut oil respectively. The increase in the polenske value in the coconut oil adulterated ghee is mainly due to the presence of higher amount of short chain fatty acids in coconut oil. The results are in agreement with the results given by Upadhyaya, (2014)

\section{Saponification value}

Saponification value is the measure of average molecular weight of fatty acids present in the milk fat. In the present study the control, market and desi branded ghee samples recorded the saponification value of $230.66,233.0$ and 232 respectively.

From the (table 5) it is observed that there was a decrease in the value is observed in all the three ghee samples by adulterating them with the adulterants like GO, HF and ABF. There was a slight increase in the value is observed in the $\mathrm{CO}$ adulterated control ghee from 230.66 to 231.92 at 15 per cent adulteration. The results obtained are in accordance with the results given by Upadhyaya, (2014)

In conclusion the results of the present investigation showed that adulteration of ghee with different fats and oils resulted in changes in physico-chemical characteristics and some of the changes could be utilized in detecting adulteration of ghee with coconut oil, groundnut oil, hydrogenated fat and animal body fat. However, the changes in values of several physicochemical characteristics as a result of adulteration were not sensitive enough to detect adulteration and may be an 
indication for adulteration having fair knowledge of impact of blending the adulterants on physicochemical characteristics was essential.

\section{References}

Aneja, R. P., Mathur, B. N., Chandan, R. C., Bannerjee, A. K. and Guptha, P. R., 1990.Technology of Indian Milk Products, (Dairy India Publication, New Delhi, India). Section 3.4: Fat Rich Dairy Products 187.

Bolton, E.R., 1999. Oils Fats and Fatty Foods: Their Practical Examination. 1st Edn., Biotech Books, Delhi, India, ISBN-13: 9788176220286, pp: 22-301.

DE, S., 2005. Outlines of Dairy Technology. Oxford University Press, New Delhi, 382-466.
Doctor, N.S., et al., (1940) Indian J.Vet. Sci. 10 (10): 63- 79.

Jenness, R. and Patton, S., 1959. Principles of Dairy Chemistry. John Wiley \& Sons Inc.

SP: 18 (Part XI) - 1981. ISI Handbook of food analysis part XI Dairy Products, India Standards Institution, New Delhi.

Upadhyay, N., 2014. Detection of Vegetable Oil and Animal Body Fat In Ghee Using Solvent Fractionation Technique. (Doctorial dissertation, NDRI, Deemed University), Karnal, India.

Zachariah, SP., Parmar SC., Bhavadasan MK., Nath BS., 2010. Detection of adulteration of ghee with coconut oil or palm oil. Indian J Dairy Sci. 63, 278282.

\section{How to cite this article:}

Niranjan, G. Poojitha, C. Kempanna and Shilpashri, B. G. 2020. Effect of Blending of Fats and Oils on Physico-chemical Properties of Ghee. Int.J.Curr.Microbiol.App.Sci. 9(08): 1127-1132. doi: https://doi.org/10.20546/ijcmas.2020.908.124 